\title{
THE INDONESIAN-ENGLISH CODE-MIXING IN JUST ALVIN SHOW AT METRO TV
}

\author{
Enggar Mulyajati \\ Universitas Indonesia \\ enggarmulyajati@gmail.com
}

\begin{abstract}
Globalization requires Indonesian people to master international language, English. At first Indonesian bilingual speakers speak vernacular and Indonesian language yet nowadays they speak Indonesian language and English. The use of English occurs not only in formal situation but also informal situation. Bilingual speakers used to mix their English to Indonesia language in informal conversation, which is called codemixing. The symptom of code-mixing in informal situation is found in Just Alvin talkshow at Metro TV. This research is aimed at discovering the types of code-mixing and syntactic units are mixed in the speeches. The data of this qualitative research is conversation transcriptions. The result shows that there are three types of code-mixing and three syntactic units found. The types of code-mixing are insertion, alternation, and congruent lexicalization. While the syntactic units mixed in the conversation involve words, phrases, and clauses.
\end{abstract}

Keywords: bilingualism, code-mixing, Just Alvin

\begin{abstract}
ABSTRAK
Perkembangan globalisasi menuntut masyarakat Indonesia untuk menguasai bahasa Inggris yang merupakan bahasa internasional. Apabila pada awalnya masyarakat Indonesia merupakan penutur bilingual bahasa daerah-bahasa Indonesia, saat ini kebanyakan dari mereka menjadi penutur bilingual bahasa Indonesia-bahasa Inggris. Penggunaan bahasa Inggris dalam percakapan tidak hanya dalam ragam formal tetapi juga informal. Penutur bilingual terbiasa menyisipkan bahasa Inggris dalam tuturan bahasa Indonesia, yang disebut juga campur kode. Gejala campur kode dalam ragam informal ditemukan pada percakapan di acara tayang bincang Just Alvin di Metro TV. Penelitian campur kode ini bertujuan untuk menemukan jenis-jenis campur kode dan satuan sintaksis apa saja yang dicampurkan penutur dalam tuturannya. Penelitian ini adalah penelitian kualitatif dengan data berupa transkripsi percakapan. Hasil penelitian menunjukkan terdapat tiga jenis campur kode dan tiga satuan sintaksis. Jenis-jenis campur kode tersebut meliputi penyisipan, alternasi, dan leksikalisasi kongruen. Sementara satuan sintaksis yang ditemukan berupa kata, frasa, dan klausa.
\end{abstract}

Kata Kunci: bilingualisme, campur kode, Just Alvin

\section{INTRODUCTION}

\section{Background of the Study}

At first bilingualism in Indonesia can be seen from the use of vernacular and Indonesian language by the society to communicate each other. Along with the era of globalization, communication is steadily growing not only in national but also in international coverage. Bilingualism in Indonesia is no longer only in the use of vernacular and Indonesian language but also in Indonesian and English. This bilingual phenomenon causes bilingual speakers to choose code and strategy of interaction used in particular context (Saville-Troike, 2003, p. 42). The forms of interaction used are codeswitching and code-mixing.
A number of linguists describe the notion of code-switching and code-mixing. Kridalaksana (2008, p. 9) stated that codeswitching is an adjustment strategy using language variation in a speech event. The speakers switch one language code to another consciously and is usually caused by the change of situation from formal to informal, topic substitution, participants, etc. While code-mixing is a mixing of particular elements like words and phrases from other language. Meyerhoff (2006, p. 120) differentiated between code-switching and code-mixing based on the situations, codeswitching takes place in formal situations while code-mixing takes place in informal situations. The difference between codeswitching and code-mixing is not only based on the situation but also the level of sentence. 
Suhardi $(2009$, p. 45) explained that codeswitching occurs beyond the limit of sentence while code-mixing occurs in the boundary of sentence. Based on those linguists' notions, the difference between code-switching and code-mixing can be seen clearly. However, Muysken (2000, p. 4) uses term 'codemixing' to encompass code-switching and code-mixing phenomena because this term is considered to have neutral meaning because code-switching is a type of alternation. Therefore, the researcher used the term codemixing for all code-switching and codemixing phenomenon in this study.

Code-mixing phenomenon occurs because each speaker has different language background. Language skills from a speaker can be seen from how it's used to communicate. It's common for speakers to insert other language expressions while having conversation in informal situation because of relax and natural atmosphere. Code-mixing conversation in informal situation can be found in radio conversation, entertainment news, and talkshow.

The symptoms of the IndonesianEnglish code-mixing are found in Just Alvin talkshow at Metro TV. The show hosted by Alvin Adam invites many speakers to discuss specific themes. Based on four main characters; namely friendship, trust, untold, and achievement, this show carries an indepth interview but does not put aside the comfort for the speakers. By establishing comfort, the trust of the speakers will appear so they can convey facts that they do not tell to other infotainment. By the end of the show, the viewers can get good value from the conversation.

The speakers of Just Alvin show have diverse background, such as background of education, languages, and jobs. In each aired episodes, many speakers mix their language by inserting English into Indonesian. The expressions inserted in the conversation are words, phrases, and clauses. Muysken (2000, p. 3) classified three types of code-mixing; namely insertion, alternation, and congruent lexicalization.

\section{Objectives of the Study}

Based on the code-mixing phenomenon in Just Alvin show, the researcher is interested to investigate the types of code-mixing and syntactic units mixed in the speech. This study aims at discovering the types of code-mixing and syntactic units in the conversation.

\section{LITERATURE REVIEW}

\section{The Notion of Code-Switching and Code- Mixing}

In a bilingualism situation, bilingual speakers often change their language varieties according to the needs and circumstances. They develop the strategy of language choice because of limitation of language use in certain contexts, participants, and topics (Bonvillain, 2003, p. 336). Therefore, the languages used by bilingual speakers show social functions. Bhatia and Ritchie (2008) argued that bilingual speakers are not only able to switch one language to another easily and precisely but they are also capable of mixing other language to communicate if it is necessary. These phenomena are called codeswitching and code-mixing.

When bilingual speakers communicate each other, they often mix elements from particular language in a sentence or discourse which is called codeswitching. According to Ohoiwutun (1997, p. 69 ), code-mixing is defined as the use of more than one code or language in a discourse. While code-switching is the switch of the use of a language to another language, dialect to language, or other dialect. Coulmas (2013, p. 124) describes code-switching occurs when the speakers are able to distinguish clearly two language used while having conversation. In addition, Meyerhoff (2006, pp. 116-120) differentiate codeswitching as an alternation of language varieties or codes that occurs between sentences or within clause boundaries. While code-mixing is an alternation of language varieties or codes that occurs in a clause or phrase.

On the other hand, some linguists do not distinguish between code-switching and code-mixing. Wardhaugh (2006, p. 101) stated that code-switching or code-mixing occurs when bilingual/multilingual speakers are required to choose language code and they have to switch or mix one code to another in their short speech so they create new code. In addition, Muysken (2000, p. 4) used the term code-mixing instead of codeswitching for all code-mixing and codeswitching phenomena. He stated the term of 
code-mixing is considered as less neutral because code-switching is the type of alternation in code-mixing, besides the term code-switching will distinguish between code-mixing, borrowing, and interference. His statement is in line with Hamers and Blanc (1993, p. 152) who argued that codeswitching removes all elements in language level and lexical units in a sentence, so it is not easy to distinguish between codeswitching and code-mixing.

\section{Code-Mixing}

The incorporation of lexical elements from two languages is called code-mixing. Muysken (2000, p. 1) used code-mixing term to all lexical and grammatical elements of two languages mixed in a sentence. Codemixing that occurs in a sentence is called intrasentential code-mixing. Code-mixing in bilingual speeches explained by Muysken (2000, p. 3) consists of three types; namely insertion, alternation, and congruent lexicalization.

In code-mixing, insertion of language elements occurs. The inserted element is called constituent. A constituent is a syntactic unit that can be either lexical or phrase. The insertion of single element in a sentence is called well-defined insertion. While there are two code-mixed elements are drawn in a sentence, it may be termed the adjacency principle. In insertion, the switched elements tend to be content words rather than function words, like nouns, adjectives, and verbs. Another diagnostic feature of insertion is morphological integration which particularly strikes in the case of verbs and quantifiers.

Alternation explained by Muysken (2000, p. 96) as the most common codemixing strategy, which two languages present in clause forms but are relatively separated. The term alternation is used by Muysken to substitute code-switching. In alternation there are several switches of constituents in one utterance because the speakers simultaneously switch the variety or language. The insertion can occur when the constituent is initiated and followed by elements of another language and the element is structurally connected. On the contrary, if elements of other languages which initiate and follow switched language are not structurally connected then it is most likely an alternation. In the alternation the more words are contained in a switching fragment the closer to the alternation. Thus the alternation takes into account the complexity and length of fragments in an utterance. When insertion is marked with full words such as nouns and adjectives, the alternation can be marked with discourse particles, interjections, adverbs and adverbial modifications (Muysken 2000, pp. 96-98). In some cases the alternation code mix involves adverbial modification, i.e. the use of foreign adverbs or adverbial phrases. Another feature of alternation is not only to be found at the internal level of the sentence, but also embedded in discourse. If in an utterance there is a mixed clause beginning with language $A$, then language $B$ is used as the following clause. Doubling is another feature of alternation. Doubling is marked by language redirects beginning with language $\mathrm{A}$ and followed by language $B$ with the intent of repeating and clarifying the speech. Flagging also becomes an indicative feature of alternation by inserting dummy elements. Dummy element is an element that has a syntactic function but does not have a semantic function.

In congruent lexicalization, there are linear and structural alignments at the level of language syntax. Moreover, another feature of congruent lexicalization is the mixing of constituents. Congruent lexicalization tends to show non-nested $\mathrm{a} b$ a structure because element $b$ is not related to well-defined elements. Another feature of this process is the mixing of idioms and collocations caused by the structures involved in having interrelated lexicon together. Furthermore, another feature of congruent lexicalization is non-constituent mixing. This mixing cannot be accommodated by a theory that has syntactic restrictions. All categories can be transferred in congruent lexicalization, including the word task, since no matrix language determines the language of the word assignment. Additionally congruent lexicalization involves bidirectional code mixing which is due to the absence of the dominant language matrix. Back-and-forth switch in congruent lexicalization is often found because there is no dominant matrix language. 


\section{RESEARCH METHOD}

\section{Research Design}

The research of the EnglishIndonesian code-switching in Just Alvin show uses qualitative approach. Qualitative research is described by Creswell (2014, p. 110 ) as a study that explores a concept of phenomenon. In this research, data is obtained through recording. The transcriptions of conversation are collected, reduced, and analyzed in depth to answer the research questions. Hence, this study is categorized as a qualitative research.

\section{Sources of Data}

The data in this study is oral conversations in Just Alvin show from January to December 2015. However, researchers only take samples that represent the entire shows.

\section{Data Sampling}

To determine the number of samples the researcher uses purposive sampling technique. Purposive sampling or also called judgmental sampling is sampling based on the conditions set by the researchers (Ulwan, 2014). Therefore, the sample criteria for the study are the title of the episode of the event written in English and the resource person is a public figure /professional. The conversation data is transcribed using the Rosenfelder linguistic transcription convention guidelines (2011).

\section{FINDINGS AND DISCUSSION}

Based on the conversation analysis, there are three types of code mixes in the speech that are insertion, alternation, and congruent lexicalization. Code-mixing is dominated by 348 speech fragments of insertion (61.92\%), followed by 203 speech utterances of alternation (36.12\%), and 11 speech fragments of congruent lexicalization $(1.96 \%)$. Most speakers do insertion in mixed speech followed by alternation. While congruent lexicalization is the least occurs in conversation.

The code mixing type in Just Alvin show is dominated by insertion. Insertion is classified in the single constituent insertion feature, adjacency principle, and morphological integrated constituents. In the insertion of a single constituent, the inserted constituents are words and phrases. Data and analysis of single constituent insertion are as follows.

(1) Jadi ceritanya gimana di subway itu?

(2) Ada yang nanya tapi nanyanya, ada yang nanya pasti kan tapi lebih aku pikir mereka concern aja lah gitu.

(3) Cuma kalau sop itu terlalu strong ya.

(4) Semua orang pingin jadi celebrity chef.

(5) Dulu kalau kita pertama masuk dunia artis kan show off ya hidupnya.

(6) Nah buku kedua itu mengenai Indonesian heritage.

Based data above, the constituent of insertion are nouns, verbs, and adjectives. In addition, noun phrases and adjective phrases are also inserted in the middle of sentence. In the data (1) the constituent subway is inserted in the middle of the sentence. Same as data (1), data (2) and (3) constituents concern and strong are also inserted in the middle of the sentence. Meanwhile data (4) - (6) are the insertion of phrase. In data (4) the noun phrase celebrity chef is inserted at the end of the sentence. Next, on data (5) the constituent in the form of a verb phrase show off is inserted at the end of the sentence. Finally, data (6) shows constituent Indonesian heritage which is adjectival phrase is inserted at the end of the sentence.

The adjacency principle is the insertion of more than one constituent in a sentence. Insertion of double constituents analysed in data are words and phrases including nouns, verbs, and adjectives. The data and analysis are presented below.

(7) Tapi lebih suka condong ke masakan western atau masakan traditional?

(8) Maksudnya dalam hidup itu kita harus tetap traveling ya supaya makin contain aja - supaya makin isi aja.

(9) $\mathrm{Di}$ bidang industri hiburan kelihatannya - saya enggak bilang menghilang sih tapi kelihatan enggak picky juga tapi memang mau enggak mau lebih untuk memilih tepat di usia dan performancenya --

(10) Tapi ada beberapa juga makanan Indonesia memang eee family packages - memang family serving ya. 
(11) Bisa jadi di mana kak, pokoknya sesuai dengan path aku mau yang mau soul traveler aja.

Based on data, the insertion of double constituents is found in the middle of the sentence. In addition, the inserted constituents may be derived from the same or different word classes. As in data (8) the constituents inserted are verbs: traveling and contain. While in the data (9) there is mixing constituents with suffixes; picky and performancenya. Furthermore, data (10) shows adjacency insertion in the form of noun phrases inserted in the middle of the sentence, the family packages and family serving. Finally, in data (11) there is a mixing of constituents of different word classes which are noun path and noun phrase soul traveler.

In the integrated insertion morphologically the constituents obtain affixation, in the form of prefixes, suffixes, and confixes. Here are the data and analysis.

(12) Katanya kalau misalnya terlalu dipush anaknya takutnya begitu besar --

(13) Yang sekarang acceptancenya lebih banyak daripada yang dulu?

(14) Lihat aja teaser-teasernya ya bu --

(15) Nah pas lagi menginvestkan di sesuatu enggak nyangka tiba-tiba balik aja gitu keadaan.

The code-mixing data above is morphological integration type of insertion. In the data (12) constituent push (v) gets a prefix in- becomes dipush meaning 'pushed'. While in the data (13) constituent acceptance (n) gets suffix -nya become acceptancenya meaning 'the acceptance'. Data (14) shows the reduplication of constituent with suffix -nya into teaser-teasernya meaning 'the teasers'. Finally, the data (15) indicates that the constituent menginvestkan gets confix me-kan meaning 'investing'.

The second type of code-mixing is the second most likely occurs after insertion. Alternations are characterized by discourse particles, adverbs and adverbial modifications, interjections, flagging, doubling, and embedded in discourse. The data and analysis are presented below.

(16) Saya merasa roh saya tidak diisi dengan keluarga because you can have success in work, friends, social tapi saya kangennya sama keluarga -

(17) Karena itu yang socially unacceptable people you'd be a chef.

(18) Mungkin apa ya - orang-orang, ah $\boldsymbol{m y}$ people, my society, my citizen memang sayang banget ya sampai perhatian seperti itu walaupun caranya kadang dari dulu sampai sekarang enggak berubah ya --

(19) Sebenarnya Sandra Djohan Cook itu it's because I still cook until today, gitu lho.

(20) Karena kan pas like I said we were very poor. Kita sangat miskin, sangat susah.

(21) Sehat dalam arti adalah stop bullying other person, stop bullying eee --

Data (16) is an alternation utterance characterized by discourse particles in the form of conjunctions. The conjunction because marks the alternation of English clause because you can have success in work, friends, social in the middle Indonesian fragment Saya merasa roh saya tidak diisi dengan keluarga and tapi saya kangennya sama keluarga. The alternation marked by adverbial modification is shown by data (17) which constituent social (adj) get the suffix ly into adverb socially. The adverb socially marks the alternation in the form of socially unacceptable people clause you'd be chef following the Indonesian fragment Karena itu yang. Furthermore, data (18) is an alternation utterance marked by interjections $a h$ which marks the transition of Indonesian speech into English in the form of noun phrase my people, my society, my citizen. Data (19) shows the alternation of flagging indicated by dummy element $i t$ in the clause it's because I still cook until today in the middle of the sentence. Furthermore, doubling of the alternation is shown in the data (20) which clause like I said we were very poor is doubled by being translated into Indonesian clause 'kita sangat miskin'. Finally, data (21) shows the clause stop bullying of other person stop bullying embedded in the discourse. In this data the alternation clause is embedded at the end of the sentence.

The third type of code-mixing is congruent lexicalization. In congruent lexicalization, there is a linear and structural alignment at the level of language syntax. In addition, the congruent lexicalization of the 
conversations on the show is characterized by idiom and collocation. The data and analysis are presented as following.

(22) Umur empat belas tahun saya after school kalau enggak liburan sekolah $\boldsymbol{I}$ worked.

(23) Oke, kita off the record ya.

(24) Dulu kalau kita pertama masuk dunia artis kan show off ya hidupnya.

The data (22) includes congruent lexicalization because of the alignment of the syntactic structure. The lines are contextualized so that speaker mixes the clause in the past tense $I$ worked. In addition there is a prepositional phrase after school in the sentence. Furthermore, congruent lexicalization characterized by idiom is shown by data (23) in the form of an adverbial phrase off the record meaningful speech or conversation conveyed is confidential and not disseminated (Cambridge Idioms Dictionary). Finally, data (24) is a congruent lexicalization utterance marked by a collocation show-off mixed in the middle of a sentence.

\section{CONCLUSION}

In a conversation on Just Alvin's talk show there are three types of code mixes: insertion, alternation, and congruent lexicalization. Insertion most often occurs in code-mixing utterances followed by congruent alternation and lexicalization. In this type of insertion, the marking features are the insertion of a single constituent, the adjecancy principle, and morphological integration. Constituents inserted in the form of words in the form of nouns, verbs, and adjectives. In addition, speakers also insert noun phrases, verbs, and adjectives in the speech. The second type is the alternation marked by discourse particles, adverbs and adverbial modifications, interjections, tagging, multiplication, and embedding in discourse. Alternation in code-mixing utterences occurs in the form of clause inserted in the middle and end of sentence. The third type is congruent lexicalization characterized by structural and grammatical alignments, idioms, and collocations. Finally, the syntactic units that appear in the conversation analysis are words, phrases, and clauses.

\section{REFERENCES}

Bloomfield, L. (1935). Language. London: Allen and Unwin.

Bonvillain, N. (2003). Language, culture, and communication: The meaning of messages. New Jersey, NJ: Prentice Hall.

Cambridge Idioms Dictionary $\left(2^{\text {nd }} E d\right)$. (2006). Cambridge, MA: Cambridge University Press.

Coulmas, F. (2013). Sociolinguistics: The study of speakers' choices. Cambridge, MA: Cambridge University Press.

Creswell, J. W. (2014). Research design: Qualitative, quantitative, and mixed methods approaches. ( $4^{\text {th }}$ ed.). Washington, DC: Sage Publications.

Kridalaksana, H. (2008). Kamus linguistik $\left(4^{\text {th }}\right.$ Ed.). Jakarta: PT Gramedia Pustaka Utama.

Meyerhoff, M. (2006). Introducing sociolinguistics. New York, NY: Routledge.

Muysken, P. (2000). Bilingual speech: A typology of code mixing. Cambridge, CA: Cambridge University Press.

Nababan, P. W. J. (1991). Sosiolinguistik: Suatu pengantar. Jakarta: P.T. Gramedia Pustaka Utama.

Ohoiwutun, P. (1997). Sosiolinguistik: Memahami bahasa dalam konteks masyarakat dan kebudayaan. Jakarta: Kesaint Blanc.

Rosenfelder, I. (2011). Automatic alignment and analysis of linguistic change: Transcription guidelines. University of Pennsylvania.

Rusyana, Y. (1984). Bahasa dan sastra dalam gamitan pendidikan. Bandung: CV Diponegoro.

Saville-Troike, M. (2003). The ethnography of communication: An introduction ( $3^{\text {rd }}$ ed.). Oxford, OX: Basil Blackwell.

Suhardi, B. (2009). Pedoman penelitian sosiolinguistik. Jakarta: Pusat Bahasa Departemen Pendidikan Nasional.

Ulwan, M. N. (2014, February 20). Teknik pengambilan sampel dengan metode purposive sampling. Retrieved from http://www.portalstatistik.com/2014/02/teknik- 
pengambilan-sampel-dengan-

metode.html.

Wardhaugh, R. (2006). An introduction to sociolinguistics $\left(5^{\text {th }}\right.$ ed.). Oxford, OX: Blackwell Publishing. 